\title{
Академик Виктор Борисович Сочава как исследователь Дальнего Востока
}

\author{
СНЫТКО В.А. \\ Федеральное государственное бюджетное учреждение науки \\ Институт географии им. В.Б. Сочавы СО РАН, Иркутск, \\ Федеральное государственное бюджетное учреждение науки \\ Институт истории естествознания и техники им. С. И. Вавилова РАН, Москва \\ vsnytko@yandex.ru
}

\begin{abstract}
Аннотация. Рассмотрен вклад Виктора Борисовича Сочавы (1905-1978) в познание природы Дальнего Востока. Его исследования региона были начаты в конце 1920-х гг. и продолжались десятилетиями. Им был решен ряд проблем ботаники и физической географии, предложено районирование территории.

Ключевые слова: Сочава, Дальний Восток, ландшафты, тундра, районирование.
\end{abstract}

\section{Academician Viktor Borisovich Sochava as the researcher of the Far East}

\author{
SNYTKO V.A. \\ V.B. Sochava Institute of Geography, Siberian Branch of RAS, Irkutsk \\ S.I. Vavilov Institute for the History of Natural Science and Engineering of RAS, Moscow
}

Abstract. The contribution of Viktor Borisovich Sochava (1905-1978) to the knowledge of the Far East nature was considered. His investigations of the region were begun in the late 1920s and continued over the course of decades. He has solved a number of problems of botany and physical geography and proposed the zonation of territory.

Keywords: Sochava, Far East, landscapes, tundra, zonation.

В научном наследии выдающегося географа и ботаника академика Виктора Борисовича Сочавы (1905-1978) значительное место принадлежит региональным исследованиям. Это подмечено первыми биографами ученого. Тематику научных исследований В.Б. Сочавы Н.А. Гвоздецкий и А.Г. Чикишев [1] сгруппировали в следующие основные разделы.

1. Проблемы Севера;

2. Ботаническая география лесных провинций;

3. Общие закономерности географии растительного покрова и формирования ландшафтов;

4. Вопросы истории растительности и палеогеографии;

5. Принципы классификации растительности;

6. Теоретические вопросы ландшафтоведения;

7. Принципы и методы геоботанического и комплексного картографирования;

8. Основные принципы природного районирования;

9. Географические аспекты освоения тайги; 
10. Вопросы истории геоботаники и географии;

11. Принципы комплексности при организации географических исследований.

Ряд разделов творческого наследия В.Б. Сочавы выделены на основе его дальневосточных работ, начатых в конце 1920-х гг. и продолжавшихся десятилетиями.

Начало научно-исследовательской деятельности В.Б. Сочавы было положено еще в его студенческие годы обучения в Ленинградском сельскохозяйственном институте. В дальнейшем его научные замыслы реализовались в процессе проведения обширных экспедиционных исследований и стационарных экспериментов в самых разнообразных районах нашей страны [2, 3].

После весьма результативных ботанико-географических работ на Урале в 1929 г. В.Б. Сочава был командирован Полярной комиссией АН СССР на Дальний Восток, в Анадырский край, где изучал растительный покров тундрового ландшафта как кормовую базу оленеводства [4, 5]. В 1930 г. эти исследования продолжались в бассейне р. Пенжина, где им была открыта наивысшая вершина Каменного хребта, названная горой Стадухина [6].

В 1931-1938 гг. В.Б. Сочава вел работу по оценке тундровых пастбищ в качестве начальника полевых партий и руководителя сектора геоботаники и кормов Института оленеводства (с 1935 г. он начальник отдела оленеводства Арктического института, куда был присоединен Институт оленеводства).

В 1932 г. В.Б. Сочава изучал Анабарские тундры. На основании экспедиционных исследований тундр бассейна Анабара он разработал классификацию растительных ассоциаций и группировку их в фитоценотические ряды, обусловленную режимом влажности тундровых почвогрунтов. Изучив подгольцовые редколесья и кустарниковые горные тундры, он создал представление об инкубации (налегании) ярусов растительных сообществ, принятое многими исследователями [7].

В 1930-е гг. в его работах прослеживается интерес к выяснению истории флоры Дальнего Востока. Об эволюции западных тундр Якутии В.Б. Сочава докладывал на Первом Всесоюзном географическом съезде [8]. Результаты исследований этого периода выдвинули В.Б. Сочаву в число крупнейших тундроведов и определили одно из важных направлений в его научной и организационной деятельности. В.Б. Сочава первым употребил в научной литературе термин «тундроведение» и дал анализ основных понятий в этой области знаний. Помимо огромной работы по инвентаризации тундровых пастбищ и обоснованию научных основ развития оленеводства, В.Б. Сочава внес вклад в разработку теоретических проблем тундроведения, таких как четвертичная история и динамика тундровых ландшафтов, генезис пятнистых тундр, причины безлесья тундр, классификация и фитоценотические ряды тундровых ассоциаций. Он создал первое руководство по геоботаническим исследованиям в тундре. В 1933-1938 гг. В.Б. Сочава редактировал начатую по его инициативе серию выпусков «Советское оленеводство» (вышло в свет 11 выпусков), которая содержала статьи, положившие начало научной разработке многих вопросов тундрового оленеводства как важнейшей отрасли экономики Арктики.

Исследования растительности тундр были обобщены В.Б. Сочавой вместе с Б.Н. Городковым в первом томе монографии «Растительный покров СССР» «Арктические пустыни и тундры» (1956 г.) [9]. Ими были составлены общий обзор и разделы: «Горные тундры»; «Моховые и лишайниковые тундры»; «Кустарничковые тундры»; «Тундровые ивняки»; «Ерниковые тундры».

Работы на Дальнем Востоке дали В.Б. Сочаве материал для разработки широкого круга географических и геоботанических проблем, в том числе палеогеографических: о происхождении и возрасте высокогорной флоры, взаимоотношениях растительных сообществ дальневосточных лесов и их динамике, о происхождении «аянского» и «маньчжурского» типов флоры и растительности в связи с историей ландшафта, о связи растительного покрова с циркуляцией атмосферы.

Материалы исследований юга Дальнего Востока послужили основой докторской диссертации В.Б. Сочавы, а также для последующих широких обобщений в области изучения 
закономерностей ландшафтов и растительного покрова, в том числе их происхождения, эволюции и динамики.

Ярко проявился интерес у В.Б. Сочавы к комплексным географическим исследованиям в конце 1930-х гг, когда он участвовал в работах по составлению ландшафтной карты нашей страны, проводившихся под руководством Б.Н. Городкова. Тогда же решались и вопросы ландшафтного подхода в региональных исследованиях [3].

Основные теоретические идеи В.Б. Сочавы в области физической географии формировались в начале 1950-х гг., когда он преподавал на географическом факультете Ленинградского университета. Их он доложил в обобщенной форме на первом Всесоюзном совещании по ландшафтоведению, которое организовало Географическое общество СССР в 1955 г. в Ленинграде. Как пишет А.Г. Исаченко, «....его выступление на этом совещании содержит мысли, верность которых подтвердила последующая история нашей науки и которые во многом опередили свое время» [10, с. 150]. Главным было обращение внимания В.Б. Сочавы на функциональный подход в познании ландшафта.

Во второй половине 1950-х гг. деятельность В.Б. Сочавы связана с активными экспедиционными исследованиями на Дальнем Востоке и в Сибири. В 1957 г. Ботанический отряд Ботанического института АН СССР в составе Амурской комплексной экспедиции СОПС АН СССР под руководством В.Б. Сочавы работал в зоне южной тайги и подзоне хвойношироколиственных лесов (район Зейско-Амурского междуречья). Были осуществлены:

1. Разработка методики составления комплексной биологической карты.

2. Составление карты масштаба $1: 10000$ на типичный участок в подзоне хвойно-широколиственных лесов для углубленных многолетних фитоценотических, экологических и биотических работ на стационарных участках [11].

Особо значимыми были стационарные исследования биогеоценологической направленности. В 1958 г. под руководством В.Б. Сочавы было положено начало стационарных географических исследований в Забайкалье.

На первом совещании географов Сибири и Дальнего Востока в 1959 г. в Иркутске директор Института географии Сибири и Дальнего Востока СО АН СССР В.Б. Сочава, определяя первоочередные проблемы экспериментальной географии и задачи комплексных исследований, отметил: «Назрел вопрос об организации сети физико-географических стационаров, осуществляющих полный комплекс физико-географических исследований в условиях, типичных для различных природных провинций» [12, с. 4].

На первом этапе предполагалась организация таких стационаров в южной тайге Средней Сибири, в степях Южного Забайкалья и в высокогорьях Саян и дальнейшее развитие их сети в Сибири и на Дальнем Востоке. Одной из важнейших задач стационаров В.Б. Сочава считал развитие учения об элементарной физико-географической системе (фации), которое должно послужить теоретической основой для качественной оценки земель [13]. При этом он указывал, что типология фаций как комплексная проблема, которую географам разных направлений необходимо решать коллективно, нуждается в создании специальной организации - сети физико-географических станций.

В 1960-1970-е гг. отмечен также интерес В.Б. Сочавы к проблемам Дальнего Востока. Особо рассматривались вопросы районирования территории и использования ее природного потенциала. В.Б. Сочавой глубокому анализу были подвергнуты горные ландшафты, в частности гольцы Дуссе-Алиня и Северного Сихотэ-Алиня [14]. Было предложено оригинальное физико-географическое районирование [15], основанное на теоретических разработках и глубоком знании природы региона. Им были выделены четыре области: Амуро-Сахалинская, Притихоокеанская, Яно-Колымская, Байкало-Джугджурская (последние две только частью входят в пределы Дальнего Востока).

В.Б. Сочава многие годы занимался координацией географических исследований Азиатской России. Он организовал Бюро сибирских и дальневосточных организаций Географического общества СССР, которое под его руководством провело во Владивостоке 
совещания географов Сибири и Дальнего Востока в 1962 и 1973 гг. На них решались актуальные комплексные географические проблемы.

Исследования на Дальнем Востоке дали также В.Б. Сочаве материал для разработки и создания учения о геосистемах [16].

\section{Литература}

1. Гвоздецкий Н.А., Чикишев А.Г. Выдающийся советский географ и геоботаник (к 60 -летию со дня рождения В.Б. Сочавы) // Землеведение. 1967. Т. 7(47). С. 299-314.

2. Воробьев В.В., Снытко В.А. Виктор Борисович Сочава // Творцы отечественной науки. Географы. М.: АГАР, 1996. С. 538-548. $94 \mathrm{c}$.

3. Виктор Борисович Сочава (жизненный путь, научное творчество). Новосибирск: Изд-во СО РАН, 2001.

4. Сочава В.Б. О пятнистых тундрах Анадырского края // Тр. Полярной комиссии АН СССР. 1930. № 2. C. $51-68$.

5. Soczawa. Das Anadyrgebiet. Botanisch-geographsch Beobachtungen im anssersten Nordosten Asiens // Zeitschr. Ges. Erdkunde. Berlin, 1930. № 7/8. Р. 241-263.

6. Сочава В.Б. Гора Стадухина на крайнем северо-востоке Азии // Природа. 1930. № 11/12. С. 1172-1174.

7. Сочава В.Б. Растительные ассоциации Анабарской тундры // Ботан. журн. СССР. 1934. Т. 19, № 3. C. 264-304.

8. Сочава В. Б. Ботанико-географические подзоны в западных тундрах Якутии // Тр. Первого Всесоюз. геогр. съезда. Л., 1934. Вып. 3. С. 311-312.

9. Сочава В.Б., Городков Б.Н. Арктические пустыни и тундры // Растительный покров СССР. Т. 1. М.: Изд-во АН СCCP, 1956. С. $61-138$.

10. Исаченко А.Г. Совместная работа в Ленинградском университете // Виктор Борисович Сочава. Жизненный путь и научное творчество. Новосибирск, 2001. С. 147-151.

11. Сочава В.Б. Биологические комплексы районов нового освоения, их рациональное использование и обогащение. М.; Л., 1959. С. 7-18.

12. Сочава В.Б. Задачи в области физической географии Сибири и Дальнего Востока // Материалы Первого совещания географов Сибири и Дальнего Востока (Иркутск, 18-24 сентября 1959 г.). Иркутск, 1959. Вып. 1. C. 4-10.

13. Сочава В.Б. Исходные положения типизации таежных земель на ландшафтно-географической основе // Докл. Института географии Сибири и Дальнего Востока. 1962. Вып. 2. С. 14-23.

14. Сочава В.Б. Географические аспекты сибирской тайги. Новосибирск: Наука, 1980. 256 с.

15. Сочава В.Б. Опыт деления Дальнего Востока на физико-географические области и провинции // Докл. Института географии Сибири и Дальнего Востока. Иркутск, 1962. Вып. 1. С. 23-33.

16. Сочава В.Б. Введение в учение о геосистемах. Новосибирск: Наука, 1978. 319 с.

\section{References}

1. Gvozdetsky, N.A., Chikishev, A.G. Outstanding Soviet geographer and geobotanist (by the sixtieth anniversary from the birthday of V.B. Sochava). Earth science. 1967. V. VII (XLVII). P. 299-314. (In Russian)

2. Vorobyev, V.V., Snytko, V.A. Viktor Borisovich Sochava. Creators of the national science. Geographers. Moscow: AGAR, 1996. P. 538-548. (In Russian)

3. Viktor Borisovich Sochava (life journey, scientific work). Novosibirsk: Publ. by SB of RAS, 2001. 194 p. (In Russian)

4. Sochava, V.B. About spotted tundras of the Anadyr Krai. Proceedings of the Polar commission of USSR Academy of Sciences. 1930. No. 2. P. 51-68. (In Russian)

5. Soczawa. Das Anadyr gebiet. Botanisch-geographisch Beobachtungenimanss ersten Nordosten Asiens. Zeitschr. Ges. Erdkunde. Berlin, 1930. No. 7-8. P. 241-263.

6. Sochava, V.B. Stadukhin mountain in the extreme north-east of Asia. Priroda (Nature). 1930. No. 11-12. P. 1172-1174. (In Russian)

7. Sochava, V.B. Plant associations of the Anabar tundra. Botanic Journal of the USSR. 1934. V. 19. No. 3. P. 264304. (In Russian)

8. Sochava, V.B. Phytogeographical subzones in the western tundras of Yakutia. Proceedings of the First All-Union geographical congress. Leningrad, 1934. Iss. 3. P. 311-312. (In Russian)

9. Sochava, V.B. and Gorodkov, B.N. Arctic deserts and tundras. Vegetation cover of the USSR. V. I. - Moscow: Publ. by the USSR Academy of Sciences. 1956. P. 61-138. (In Russian) 
10. Isachenko, A.G. Collaborative work in the Leningrad University. Viktor Borisovich Sochava. Life journey and scientific work. Novosibirsk, 2001. P. 147-151. (In Russian)

11. Sochava, V.B. Biological complexes of the new development areas, their sustainable use and enrichment. Moscow; Leningrad, 1959. P. 7-18. (In Russian)

12. Sochava, V.B. Problems in the field of the physical geography of Siberia and Far East. Proceedings of the First Conference of the geographers of Siberia and Far East (Irkutsk, September 18-24, 1959). Irkutsk, 1959. Iss. 1. P. 4-10. (In Russian)

13. Sochava, V.B. Initial provisions of the taiga lands' typification on the landscape-geographical basis. Reports of the Institute of the Siberia and Far East geography. 1962. Iss. 2. - P. 14-23. (In Russian)

14. Sochava, V.B. Geographical aspects of the Siberian taiga. Novosibirsk: Nauka, 1980. 256 p. (In Russian)

15. Sochava, V.B. Experience of the Far East division into the physic-geographical areas and provinces. Reports of the Institute of the Siberia and Far East geography. Irkutsk, 1962. Iss. 1. P. 23-33. (In Russian)

16. Sochava, V.B. Introduction to theory of geosystems. Novosibirsk: Nauka, 1978. 319 p. (In Russian) 